\title{
An Investigation of Meromixis in Cave Pools, Lechuguilla Cave, New Mexico
}

\author{
David B. Levy ${ }^{1}$
}

\begin{abstract}
:
Levy D.B. 2008. An Investigation of Meromixis in Cave Pools, Lechuguilla Cave, New Mexico. International Journal of Speleology, 37 (2), 113-118. Bologna (Italy). ISSN 0392-6672.

Chemical characteristics of permanent stratification in cave pools (meromixis) may provide insight into the geochemical origin and evolution of cave pool waters. The objective of this study was to test the hypothesis that some pools in Lechuguilla Cave may be subject to ectogenic meromixis, where permanent chemical stratification is induced by input of relatively saline or fresh water from an external source. However, because organic $C$ concentrations in Lechuguilla waters are low (typically $<1$ mg $L^{-1}$ ), biogenic meromixis resulting in $\mathrm{O}_{2}(\mathrm{~g})$-depleted subsurface waters is not expected. Four pools at various depths below ground surface $(0 \mathrm{~m})$ were studied: (1) Lake Chandalar (-221 m), (2) Lake of the Blue Giants (LOBG) (- $277 \mathrm{~m}),(3)$ Lake Margaret (- $319 \mathrm{~m})$, and (4) Lake of the White Roses (LOWR) (- $439 \mathrm{~m})$. Water column profiles of temperature, $\mathrm{pH}$, dissolved $\mathrm{O}_{2}(\mathrm{~g})$, and electrical conductivity (EC) were collected down to a maximum depth of $13.1 \mathrm{~m}$ using a multi-parameter sonde. Opposite pH gradients were observed at Lake Chandalar and LOBG, where $\mathrm{pH}$ at the surface $(0.3 \mathrm{~m})$ varied by \pm 0.20 units compared to the subsurface $(>0.9 \mathrm{~m})$, and are probably the result of localized and transient atmospheric $\mathrm{CO}_{2}(\mathrm{~g})$ concentrations. At LOBG, an EC increase of $93 \mu \mathrm{S} \mathrm{cm}{ }^{-1}$ at the $0.9-\mathrm{m}$ depth suggests meromictic conditions which are ectogenic, possibly due to surface inflow of fresh water as drips or seepage into a preexisting layer of higher salinity.
\end{abstract}

Keywords: chemocline, geochemistry, meromixis, mixing, stratification, United States, Carlsbad Caverns National Park.

Received 20 December 2007; Revised 8 June 2008; Accepted 10 June 2008

\section{INTRODUCTION}

Abundant cave pools exist throughout the world whose water column may be predisposed to a condition of permanent chemical stratification (meromixis), depending on the specific effects of pool morphometry and environmental conditions. Numerous studies have been conducted regarding density stratification within the sinkholes of coastal aquifers, such as in the renowned cenotes of the Yucatán Peninsula, Mexico, although the limnological characteristics of inland, limestone-hosted freshwater cave pools have received less consideration. Meromixis in fresh water cave pools is of particular interest because the physical and chemical characteristics of stratification could provide insight into the geochemical origin and evolution of pool waters.

The physical and chemical processes leading to chemical stratification in cave pools are potentially analogous to those of permanently-stratified (meromictic) inland lakes. Over 100 meromictic lakes

1 Ph.D. 3200 Azalea Drive F4 Fort Collins, Colorado 80526 USA, davidblevy@comcast.net have been identified in North America (Anderson et al., 1985), and the estimated world-wide frequency of meromictic lakes is 1:1000 (Lindholm, 1995). Meromictic lakes have been used as tools in the study of paleolimnology and trace element redox cycling (Viollier et al., 1995; Taillefert et al., 2000; Hakala, 2005). Some meromictic water bodies also host specific bacterial populations with potential for future biotechnological applications (Overmann et al., 1996; De la Rosa-García et al., 2007).

In the classical scheme for describing meromictic water bodies, the uppermost circulating layer is the mixolimnion and the deep isolated layer is the monimolimnion. The two layers are stabilized by high total dissolved solids (TDS) concentrations in the monimolimnion, which is separated from the mixolimnion by a zone called the chemocline. Thermal stratification is also typically evident, and the monimolimnion is often depleted in dissolved $\mathrm{O}_{2}(\mathrm{~g})(\mathrm{DO})$ due to subsurface decomposition of organic C. Meromixis in a water body may be caused by: (1) input of saline or fresh water from an external source (ectogenic meromixis), (2) subsurface flow of saline water (crenogenic meromixis), or (3) decomposition of 
organic $\mathrm{C}$ leading to elevated salinity in deeper waters (biogenic meromixis) (Hutchinson, 1937).

Meromixis associated with cave and karst systems is most notable in coastal aquifers where density gradients develop between deep saline groundwater and more shallow, dilute groundwater (e.g., Mejía-Ortíz et al., 2007; Schmitter-Soto et al., 2002; Stoessell \& Coke, 2006). Cenote Verde, in Quintana Roo, Mexico, is a good example of a meromictic karst pond. Cenote Verde is the deepest known karst pond in the area (49 $\mathrm{m})$ and has seven distinguishable layers in the water column. Several of the layers contain dense bacterial populations and elevated $\mathrm{H}_{2} \mathrm{~S}(\mathrm{~g})$ concentrations (> $25 \mathrm{mg} \mathrm{L}^{-1}$ ) resulting from anaerobic decay of organic $\mathrm{C}$ coupled with the slow exchange of groundwater (Wilson \& Morris, 1994).

The most notable occurrences of density stratification in inland caves occur in karst systems composed of soluble rocks. The high solubility of gypsum $\left(\mathrm{CaSO}_{4} \cdot 2 \mathrm{H}_{2} \mathrm{O}\right)$ can lead to a significant increase in the density of the dissolving water, causing chemical stratification which may occur in single cave pools, or on an aquifer scale (Kempe, 1972; Klimchouk, 1997). Continuous or periodic inflow of fresh water, such as vadose percolation or upward groundwater recharge, favors the persistence of density stratification (Cordingley, 1991). Klimchouk (1997) provides an excellent discussion of the bevels (flat ceilings) and facets (from horizontal notching) which form when aggressive water recharges a gypsum stratum from an underlying formation under low artesian flow. However, few studies have been conducted which pertain to meromixis in isolated, fresh-water cave pools hosted in limestone bedrock.

Lechuguilla Cave (Lechuguilla), located in New Mexico (USA), contains abundant isolated pools of various size located throughout over $195 \mathrm{~km}$ of passage. Lechuguilla is situated in carbonate rocks of the Permian Capitan Reef Complex and was formed over millions of years through an unusual process of $\mathrm{H}_{2} \mathrm{SO}_{4}$ speleogenesis (Palmer \& Palmer, 2000). Results from approximately 200 water samples collected between 1986 and 1999 show that Lechuguilla pools are dominated by $\mathrm{Ca}, \mathrm{Mg}, \mathrm{HCO}_{3}$, and $\mathrm{SO}_{4}$ (Fig. 1), due to interaction of groundwater with carbonate rocks and secondary gypsum deposits (Turin \& Plummer, 2000). Lechuguilla pool water has a $\mathrm{pH}$ between 7.5 and 8.5, $\mathrm{PCO}_{2}(\mathrm{~g})$ values greater than atmospheric $\left(10^{-1.49} \mathrm{kPa}\right)$, and is usually oversaturated with respect to calcite $\left(\mathrm{CaCO}_{3}\right)$ and dolomite $\left[\mathrm{CaMg}\left(\mathrm{CO}_{3}\right)_{2}\right]$. Vadose-zone water entering the cave as flowstone seepage and ceiling drips provides recharge to the pools, while water loss from pools can occur through overflow, evaporation, and leakage. Consequently, the pools display a range in chemical composition due to variations in bedrock mineralogy, localized evaporation rates, and residence time (Forbes, 2000; Turin \& Plummer, 2000). Typical Lechuguilla pools are of the $\mathrm{Ca}-\mathrm{Mg}-\mathrm{HCO}_{3}$ and $\mathrm{Ca}-\mathrm{Mg}$ $\mathrm{SO}_{4}$ type, although two unique pools, one representing gypsum saturation (Dilithium Pool) and another signifying extreme evapoconcentration to a $\mathrm{Mg}-\mathrm{SO}_{4}$ brine (Briny Pool) have been discovered (Fig. 1).

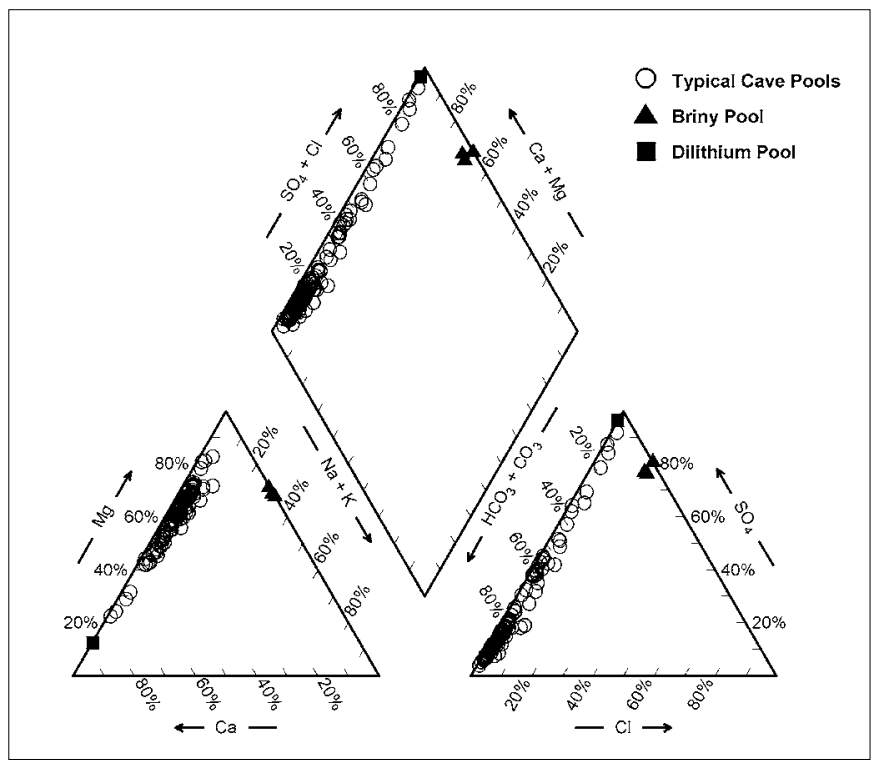

Fig. 1. Trilinear diagram illustrating the major ion compositions of Lechuguilla Cave water (data from Turin \& Plummer (2000).

Lechuguilla Cave therefore provides a suitable setting to investigate meromixis in isolated fresh water pools hosted in limestone caves. If present, chemical stratification in the pools is hypothesized to be ectogenic, resulting from the convergence of waters with contrasting salinity. Because organic C concentrations are typically low $\left(<1 \mathrm{mg} \mathrm{L}^{-1}\right)$, biogenic meromixis resulting in an $\mathrm{O}_{2}(\mathrm{~g})$-depleted monimolimnion is not expected. The discovery of common-ion effect speleothems (subaqueous helictites) in more than 30 locations demonstrates that some Lechuguilla pools have been recharged with $\mathrm{Ca}-\mathrm{SO}_{4}$ water originating from dissolution of secondary gypsum (Davis et al., 1990). The potential for extreme evapoconcentration is also evident at the Briny Pool, where both $\mathrm{Na}$ and $\mathrm{Cl}$ exceed 4,000 mg $\mathrm{L}^{-1}$ and TDS concentrations are greater than 45,000 $\mathrm{mg} \mathrm{L}^{-1}$ (Turin \& Plummer, 2000). Identification and characterization of meromixis in Lechuguilla pools could provide insight into the geochemical origin and evolution of particular pools.

\section{STUDY METHODS}

Four pools located in the Eastern and Southwestern Branches of Lechuguilla Cave, Carlsbad Caverns National Park, New Mexico (USA), were chosen for study: (1) Lake of the Blue Giants (LOBG), (2) Lake Chandalar, (3) Lake Margaret, and (4) Lake of the White Roses (LOWR) (Fig. 2). These pools were selected because they are relatively large and deep compared to the majority of Lechuguilla pools, and because they represent a range in water depth, location, and elevation within the cave (Table 1). The pools are located at distances ranging from $221 \mathrm{~m}$ below the entrance datum $(-221 \mathrm{~m})$ at Lake Chandalar, to Lechuguilla's deepest point at LOWR (- $439 \mathrm{~m})$.

In July 2007, depth profiles of temperature, $\mathrm{pH}$, $\mathrm{DO}$, and electrical conductivity (EC) were measured in each pool using a TROLL ${ }^{\circledR} 9500$ (Troll) multi-parameter sensor (In Situ, Inc., Fort Collins, Colorado, USA). The various sensors were calibrated approximately 

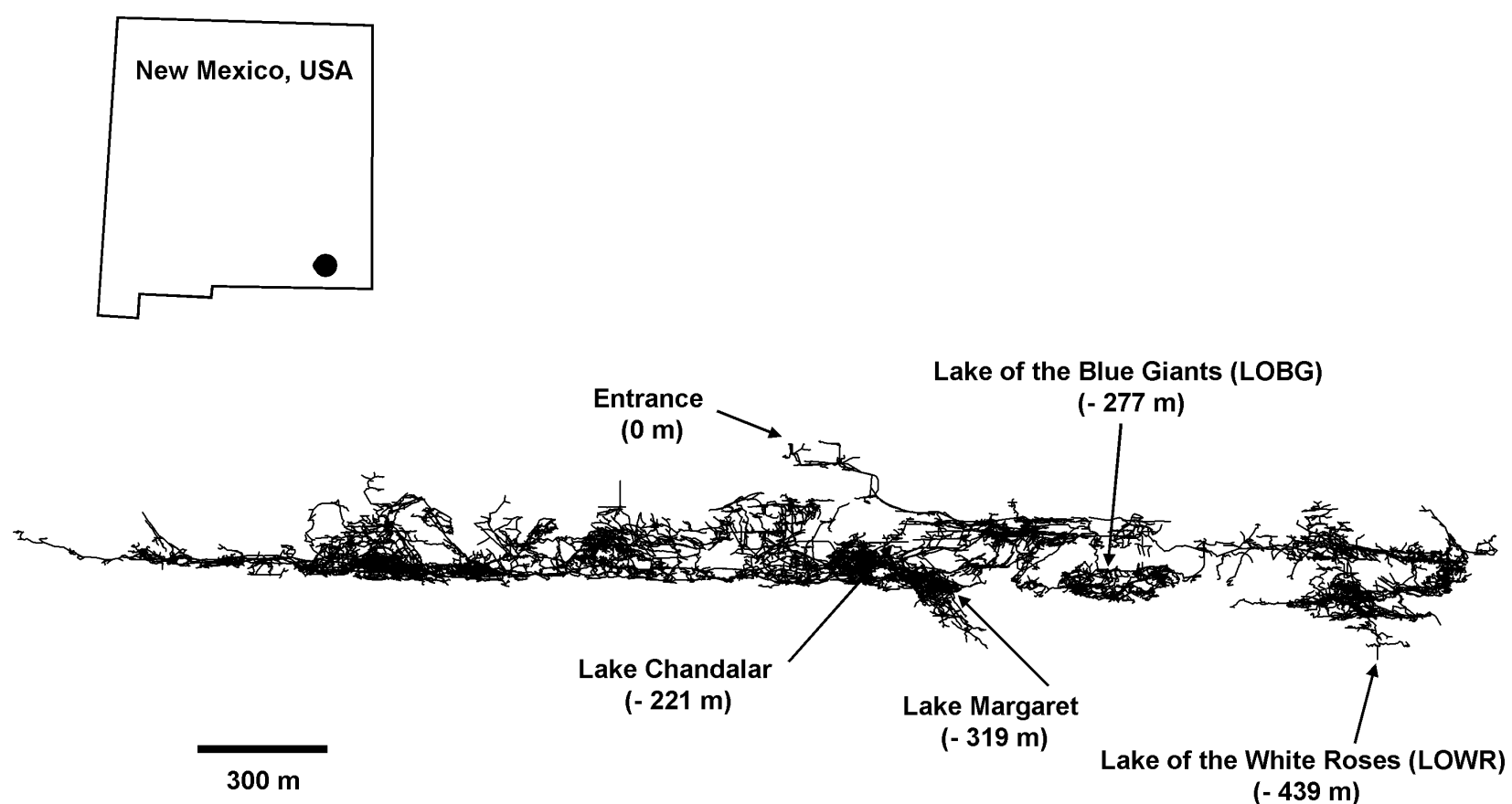

$(-439 \mathrm{~m})$

Fig. 2. Map of Lechuguilla Cave (profile) showing the entrance and locations of the pools sampled during this study. Survey data provided by Carlsbad Caverns National Park, 25 August 2007.

\begin{tabular}{|c|c|c|c|c|}
\hline Physical Parameters & Lake Chandalar a & LOBG $^{b}$ & Lake Margaret ${ }^{a}$ & LOWR $^{b}$ \\
\hline Survey Station & FE47 & GV28 & FNS11 & MNBX24 \\
\hline Station Elevation $(\mathrm{m})^{\mathrm{c}}$ & -221 & -277 & -319 & -439 \\
\hline Surface Area $\left(\mathrm{m}^{2}\right)^{d}$ & 98 & 65 & 56 & 5.0 \\
\hline Maximum Depth $(\mathrm{m})^{d}$ & 4.9 & 31 & 3.1 & 27 \\
\hline Temperature (C) & 18.4 & 19.2 & 19.4 & 20.4 \\
\hline \multicolumn{5}{|l|}{ Chemical Parameters } \\
\hline $\mathrm{pH}$ & 7.52 & 7.94 & 7.86 & 7.34 \\
\hline Bicarbonate & 140 & 256 & 228 & 310 \\
\hline Calcium & 40.1 & 26.7 & 26.1 & 33.4 \\
\hline Chloride & 2.63 & 3.5 & 2.4 & 2.9 \\
\hline Magnesium & 23.8 & 34.5 & 39.1 & 29.6 \\
\hline Potassium & 0.74 & 0.72 & 0.80 & 0.75 \\
\hline Sodium & 3.1 & 3.44 & 2.91 & 3.10 \\
\hline Sulfate & 74 & 23.1 & 15.8 & 26.4 \\
\hline \multicolumn{5}{|l|}{ Saturation Indices } \\
\hline $\mathrm{PCO}_{2}(\mathrm{~g})(\mathrm{kPa})$ & 0.39 & 0.26 & 0.23 & 1.3 \\
\hline $\mathrm{O}_{2}(\mathrm{~g})$ Saturation & 8.13 & 8.05 & 8.06 & 8.01 \\
\hline Aragonite & -0.43 & 0.09 & 0.04 & -0.17 \\
\hline Calcite & -0.28 & 0.23 & 0.18 & -0.17 \\
\hline Dolomite & -0.50 & 0.78 & 0.74 & -0.17 \\
\hline Gypsum & -1.9 & -2.6 & -2.8 & -2.5 \\
\hline
\end{tabular}

$a=$ Turin \& Plummer (2000). $b=$ sampled during the present study. c=below Entrance datum. $d=$ data courtesy of Carlsbad Caverns National Park.

Table 1. Chemical and physical properties for the pools studied. Aqueous concentrations expressed as $\mathrm{mg} \mathrm{L}^{-1}$.

$16 \mathrm{hr}$ prior to entering the cave using standard solutions for $\mathrm{pH}(7$ and 10$)$ and $\mathrm{EC}\left(147 \mu \mathrm{S} \mathrm{cm}^{-1}\right)$. The Troll measures DO concentration using an optical fluorescence sensor, which provides extremely stable and accurate DO measurements $\left( \pm 0.1 \mathrm{mg} \mathrm{L}^{-1}\right)$. The DO sensor was calibrated at 0 percent $\mathrm{O}_{2}(\mathrm{~g})$ saturation with $\mathrm{Na}_{2} \mathrm{SO}_{3}$ and at 100 percent $\mathrm{O}_{2}(\mathrm{~g})$ saturation using air-saturated $\mathrm{H}_{2} \mathrm{O}$. The Troll was advantageous for chemical profiling of cave pools because: (1) data could be collected in situ at various depths, (2) the need for carrying multiple single-parameter instruments was eliminated, and (3) instrument calibration remains stable for weeks.

Surface water samples were obtained from two of the pools (LOBG and LOWR) during July 2007. Filtered $(0.45 \mu \mathrm{m})$ samples were placed into polyethylene bottles 
with zero head space following standard procedures for water sampling and preservation (Eaton et al., 2005). Laboratory analyses were conducted by SVL Analytical, Inc. (Kellogg, Idaho, USA) in accordance with methods of the United States Environmental Protection Agency (USEPA, 1983): $\mathrm{Cl}$ and $\mathrm{SO}_{4}$ (Method 300.0), Ca, Mg, Na, K (Method 200.7), and $\mathrm{HCO}_{3}+\mathrm{CO}_{3}$ alkalinity (Method 2020B). Major ion data for the remaining two pools (Lake Chandalar and Lake Margaret, sampled 4 February 1995) were obtained from the existing compilation of Lechuguilla pool chemistry (Turin \& Plummer, 2000). The major ion data for all pools were input into the geochemical speciation model PHREEQC (Parkhurst \& Appelo, 1999) to calculate $P_{C O}(g)$ and mineral saturation index (SI) values. Saturation of $\mathrm{O}_{2}(\mathrm{~g})$ was calculated by correcting the $\mathrm{O}_{2}(\mathrm{~g})$ solubility values at the various temperatures for salinity and pressure (Radtke et al., 1998). Barometric pressure at each location was not recorded at the time of DO measurement, and was subsequently estimated using the nearest survey station (Table 1) elevation above sea level.

\section{RESULTS AND DISCUSSION}

Total pool depths range from $3.1 \mathrm{~m}$ at Lake Margaret to $31 \mathrm{~m}$ at LOBG, and the pools displayed a wide range in surface area (Table 1). However, the maximum depth which could be reached with the Troll was limited by access logistics and pool geometry at two locations (5.2 $\mathrm{m}$ at LOBG and $2.5 \mathrm{~m}$ at LOWR). Surface water chemical results (Table 1) indicate that Lake Chandalar is a $\mathrm{Ca}-\mathrm{SO}_{4}$ water, while LOBG, Lake Margaret, and LOWR are $\mathrm{Mg}-\mathrm{HCO}_{3}$ waters. Calculated $\mathrm{PCO}_{2}(\mathrm{~g})$ values of the surface waters are greater than atmospheric $\left(10^{-1.49} \mathrm{kPa}\right)$, and calculated $\mathrm{O}_{2}(\mathrm{~g})$ saturation values range from 8.01 to $8.3 \mathrm{mg}$ $\mathrm{L}^{-1}$. Lake Chandalar and LOWR were undersaturated with respect to calcite, aragonite, and dolomite, while oversaturated conditions existed in Lake Margaret and LOBG. All of the surface water samples were undersaturated with respect to gypsum, which is typical for Lechuguilla pools (Turin \& Plummer, 2000).

\section{pH Profiles}

Lake Margaret and LOWR showed little variation in $\mathrm{pH}$ with depth, although strongly opposite $\mathrm{pH}$ gradients were observed in Lake Chandalar and LOBG (Fig. 3a). Lake Chandalar displayed a 0.20 unit $\mathrm{pH}$ increase between the surface $(0.3 \mathrm{~m})$ and subsurface $(>0.6 \mathrm{~m})$, while a 0.20 unit $\mathrm{pH}$ decrease was observed between the surface $(0.3 \mathrm{~m})$ and subsurface $(>0.9 \mathrm{~m})$ at LOBG. Below the 1-m depth, however, the $\mathrm{pH}$ remained relatively constant with increasing water depth in all pools (Fig. 3a). The opposite trends in $\mathrm{pH}$ between Lake Chandalar and LOBG may reflect variations in $\mathrm{CO}_{2}(\mathrm{~g})$ fluxes between the two pools. For example, an influx of $\mathrm{CO}_{2}(\mathrm{~g})$ at Lake Chandalar $\left(P \mathrm{CO}_{2}=0.39 \mathrm{kPa}\right)$ can explain the lower surface $\mathrm{pH}$ and undersaturation with respect to calcite (Fig. 3a, Table 1), while an outflux of $\mathrm{CO}_{2}(\mathrm{~g})$ at LOBG $\left(\mathrm{PCO}_{2}=0.26 \mathrm{kPa}\right)$ is consistent with a higher surface $\mathrm{pH}$ and oversaturation with respect to calcite (Fig. 3a, Table 1).

The $\mathrm{pH}$ of Lechuguilla pools is largely a function of the degree of $\mathrm{CO}_{2}(\mathrm{~g})$ outgassing from vadose water entering the cave, the extent of which is controlled by the $\mathrm{PCO}_{2}(\mathrm{~g})$ of the cave atmosphere (Turin \& Plummer, 2000). Previous Lechuguilla researchers have shown that atmospheric $\mathrm{CO}_{2}(\mathrm{~g})$ concentrations increase with distance below ground (Cunningham \& LaRock, 1991), and that pool $\mathrm{pH}$ decreases with increasing $\mathrm{PCO}_{2}(\mathrm{~g})$ (Fig. 4). Differences between surface and subsurface $\mathrm{pH}$ values in the pools are likely the result of localized, transient atmospheric $\mathrm{CO}_{2}(\mathrm{~g})$ concentrations whose effect is most pronounced at the pool surface. Air circulation patterns in Lechuguilla are complex, and may be either barometric, convective, or stagnant depending on location relative to the entrance or other potential surface connections (Cunningham \& LaRock, 1991).

\section{EC Profiles}

Electrical conductivity profiles provide a relative indication of TDS concentrations with depth. Lake Chandalar, Lake Margaret, and LOWR displayed characteristic EC profiles which remained constant with depth below the water surface. However, at LOBG, the EC profile indicates the presence of a relatively strong chemocline between 0 and $0.9 \mathrm{~m}$, where the EC increased by $93 \pm 2 \mu \mathrm{S} \mathrm{cm} \mathrm{cm}^{-1}$ (Fig. 3b). Oversaturation with respect to calcite and dolomite in the mixolimnion $(0.3 \mathrm{~m})$, perhaps caused by lower $\mathrm{PCO}_{2}(\mathrm{~g})$ and higher $\mathrm{pH}(+0.20$ units) relative to the monimolimnion $(>0.9 \mathrm{~m})$, indicates the potential for mineral precipitation to decrease surface EC relative to deeper waters (Table 1). However, no significant variation in EC was observed at Lake Chandalar where a similar but opposite $\mathrm{pH}$ gradient existed (Fig. 3a,b), indicating that LOBG may be meromictic. Chemical stratification at LOBG is likely ectogenic, potentially caused by slow influx of fresh water into a pre-existing layer of higher salinity.

\section{Dissolved $\mathrm{O}_{2}$ Profiles}

Dissolved $\mathrm{O}_{2}(\mathrm{~g})$ measurements were obtained using an optical DO fluorescence sensor which provides extremely stable and accurate $( \pm 0.1 \mathrm{mg}$ $\left.\mathrm{L}^{-1}\right)$ results. No significant variation in $\mathrm{DO}$ was observed as a function of depth in any of the pools studied, although significant differences in DO were observed between several of the pools (Fig. 3c). Comparison of the DO profiles (Fig. 3c) to their respective calculated $\mathrm{O}_{2}(\mathrm{~g})$ saturation values (Table 1) shows that all of the measured DO values are below $\mathrm{O}_{2}(\mathrm{~g})$ saturation. Equilibrium calculations performed using PHREEQC (Parkhurst \& Appelo, 1999) indicate that the observed degree of $\mathrm{O}_{2}(\mathrm{~g})$ saturation can not be explained by the elevated $\mathrm{PCO}_{2}$ (g) levels. In addition, biological activity would not be expected to consume significant amounts of DO due to the low organic $\mathrm{C}$ concentrations (typically $<1 \mathrm{mg} \mathrm{L}^{-1}$ ) in Lechuguilla pools (Turin $\&$ Plummer, 2000; Levy, 2007). The differences 

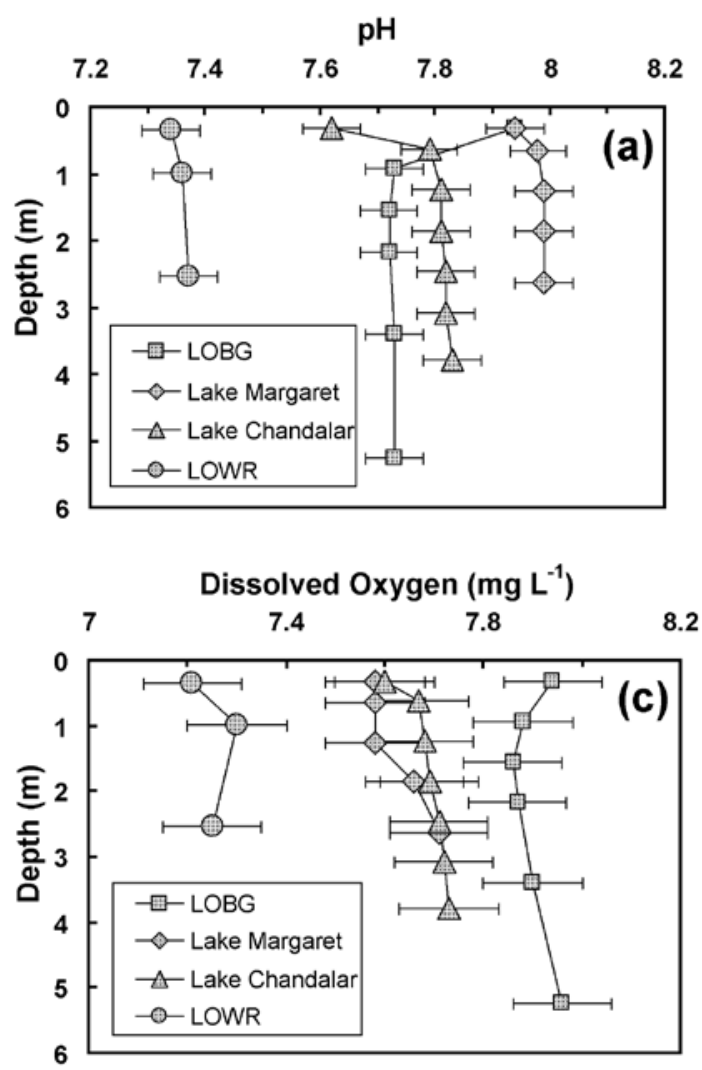

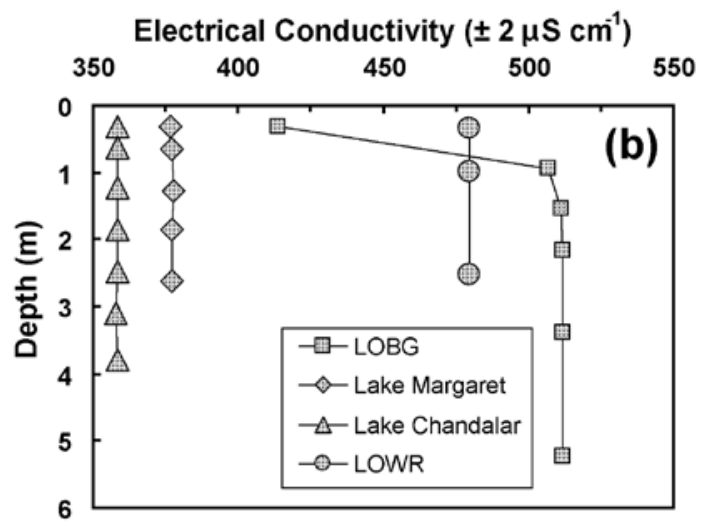

Temperature $\left({ }^{\circ} \mathrm{C}\right)$

1920

21

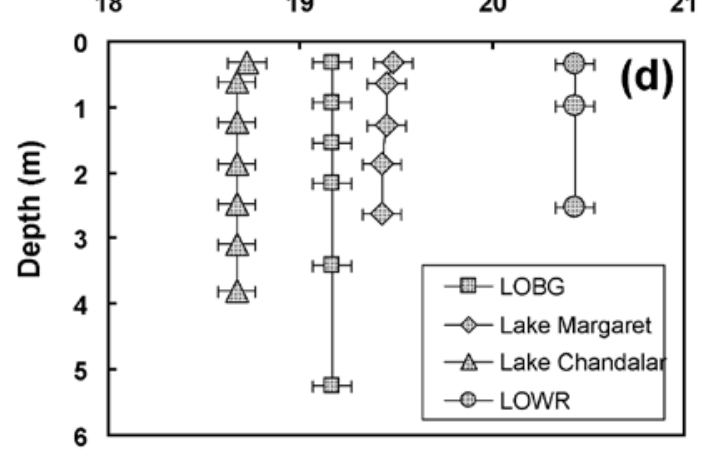

Fig. 3. Chemical profiles for the pools studied: (a) pH, (b) EC (c) DO, and (d) temperature. Error bars represent the accuracy of measurement for each sensor.

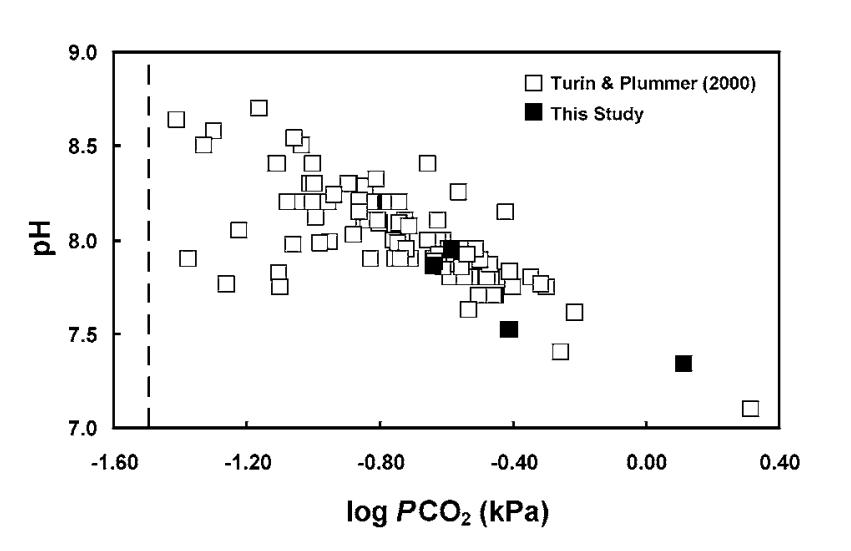

Fig. 4. Measured $\mathrm{pH}$ in Lechuguilla pools as a function of calculated $\mathrm{PCO}_{2}(\mathrm{~g})$. Dashed vertical line represents atmospheric $\mathrm{PCO}_{2}(\mathrm{~g})$.

between measured $\mathrm{DO}$ and calculated $\mathrm{O}_{2}(\mathrm{~g})$ saturation are most likely related to uncertainty in the atmospheric pressure values used to calculate $\mathrm{O}_{2}(\mathrm{~g})$ saturation.

\section{Temperature Profiles}

The temperature profiles show that the temperature of each pool remained constant with depth in the water column (Fig. 3d). The temperature of each pool is a function of the local geothermal gradient, and increased from $18.4{ }^{\circ} \mathrm{C}$ at Lake Chandalar $(-221 \mathrm{~m})$ to $20.4^{\circ} \mathrm{C}$ at LOWR (- $\left.439 \mathrm{~m}\right)$ (Table 1$)$.

\section{CONCLUSIONS}

Evaluation of chemical profiles in four Lechuguilla Cave pools indicates that both transient atmospheric and ectogenic processes may be responsible for chemical stratification in cave pools. Temperature did not vary significantly with depth below the water surface due to stable temperatures within the cave, and constant DO profiles support the hypothesis that biogenic meromixis does not produce chemical stratification due to the low organic $\mathrm{C}$ concentrations (typically $<1 \mathrm{mg} \mathrm{L}^{-1}$ ) in Lechuguilla pools. However, significant variation in $\mathrm{pH}$ and EC were observed as a function of depth in selected pools. The $\mathrm{pH}$ gradients observed at LOBG and Lake Chandalar are probably the result of localized, transient atmospheric $\mathrm{CO}_{2}(\mathrm{~g})$ concentrations whose effect is most pronounced at the pool surface. The EC gradient observed at LOBG is associated with a chemocline at the 0.9-m depth, consistent with ectogenic meromixis resulting from surface inflow of fresh water (as drips or seepage) into a pre-existing layer of higher salinity. Characterization of major ion chemistry above and below the chemocline, in conjunction with direct measurement of atmospheric $\mathrm{CO}_{2}(\mathrm{~g})$ and barometric pressure, may provide additional information to distinguish atmospheric surface effects from ectogenic processes in chemically-stratified cave pools. 


\section{ACKNOWLEDGEMENTS}

Special thanks are extended to In Situ, Inc. (Fort Collins, CO) for providing the TROLL ${ }^{\circledR} 9500$ instrument and to SVL Analytical, Inc. (Kellogg, ID) for their continued analytical support and funding for cave water research. Thanks to team members Gosia Allison-Kosior, Chris Andrews, Pat Cicero, Kristen Levy, and Kent Taylor for their support, and to Steve Klein for his assistance with sampling logistics. Dr. Jake Turin and several anonymous reviewers contributed valuable input, and helpful discussions were also provided by Dr. Chris Amrhein.

\section{REFERENCES}

Anderson R.Y., Dean W.E., Bradbury J.P. \& Love D., 1985 - Meromictic lakes and varved sediments in North America. U.S. Geological Survey Bulletin 1607, 19 p.

Cordingley J.N., 1991 - Water stratification in active phreatic passages. Cave Science, 18: 159.

Cunningham K.I. \& LaRock E.J., 1991 - Recognition of microclimate zones through radon mapping, Lechuguilla Cave, Carlsbad Caverns National Park, New Mexico. Health Physics, 61: 493-500.

Davis D., Palmer M.V. \& Palmer A.N., 1990 - Extraordinary subaqueous speleothems in Lechuguilla Cave, New Mexico. NSS Bulletin, 52: 70-86.

De la Rosa-García S.C., Muñoz- García A.A., BarahonaPérez L.F. \& Gamboa-Angulo M.M., 2007 - Antimicrobial properties of moderately halotolerant bacteria from cenotes of the Yucatan Peninsula. Letters in Applied Microbiology, 45: 289-294.

Eaton A.D., Clesceri L.S., Rice E.W. \& Greenberg A.E., 2005 - Standard methods for the examination of water and wastewater, $21^{\text {st }}$ Edition. American Public Health Association, Washington, D.C. (USA), 1368 p.

Forbes J.R., 2000 - Geochemistry of Carlsbad Cavern pool waters, Guadalupe Mountains, New Mexico. Journal of Cave and Karst Studies, 62: 127-134.

Hakala A., 2005 - Paleoenvironmental and paleoclimatic studies on the sediments of Lake Vähä-Pitkusta and observations of meromixis. Ph.D. Thesis No. 182, Department of Geology, University of Helsinki (Finland).

Hutchinson G.E., 1937 - A contribution to the limnology of arid regions. Transactions of the Connecticut Academy of Arts and Sciences, 33: 47-132.

Kempe S., 1972 - Cave genesis in gypsum with particular reference to underwater conditions. Cave Science, 49: 1-6.

Klimchouk A., 1997 - Speleogenetic effects on water density differences. Proceedings of the $12^{\text {th }}$ International Congress of Speleology: Symposium 7, Physical Speleology, 12: 161-164.

Levy D.B., 2007 - Geochemical trends in selected Lechuguilla Cave pools. Journal of Cave and Karst Studies, 69(3): 342-350.
Lindholm T., 1995 - Meromiktiska sjöar - sägerna och skyddsvärda (meromictic lakes). Vatten, 51: 12-16. (Swedish with English abstract).

Mejía-Ortíz L.M., Yáñez G., López-Mejía M. \& Zarza-González E., 2007 - Cenotes (anchialine caves) on Cozumel Island, Quintana Roo, Mexico. Journal of Cave and Karst Studies, 69: 250-255.

Overmann J., Beatty J.T., Hall K.J., Pfnnig N. \& Northcote T.G., 1996 - Characterization of a dense, purple sulfur bacterial layer in a meromictic salt lake. Limnology and Oceanography, 36: 846-859.

Palmer A.N. \& Palmer M.V., 2000 - Hydrochemical interpretation of cave patterns in the Guadalupe Mountains, New Mexico. Journal of Cave and Karst Studies, 62: 91108.

Parkhurst D.L. \& Appelo C.A.J., 1999 - User's guide to PHREEQC (version 2) - a computer program for speciation, batch-reaction, one-dimensional transport, and inverse geochemical calculations. U.S. Geological Survey WaterResources Investigation Report 99-4259, Denver, Colorado (USA), 312 p.

Radtke D.B., White A.F., Davis J.V. \& Wilde F.D., 1998 National field manual for the collection of water-quality data-dissolved oxygen: U.S. Geological Survey techniques of water-resources investigations, Book 9, Chapter A6. Accessed May 30 (2008) from http://pubs.usgs.gov/ twri/.

Schmitter-Soto J.J., Comín F.A., Escobar-Briones E., Herrera-Silveira J., Alcocer J., Súarez-Morales E., ElíasGutiérrez M., Díaz-Arce V., Marín L.E. \& Steinich B., 2002 - Hydrogeochemical and biological characteristics of cenotes in the Yucatan Peninsula (SE Mexico. Hydrobiologia, 467: 215-228.

Stoessell R.K. \& Coke J.G., 2006 - An explanation for the lack of a dilute freshwater lens in unconfined tropical coastal aquifers: Yucatan example. Gulf Coast Association of Geological Societies Transactions, 56: 785-792.

Taillefert M., Lienemann C.P, Gaillard J.F. \& Perret D., 2000 - Speciation, reactivity, and cycling of $\mathrm{Fe}$ and $\mathrm{Pb}$ in a meromictic lake. Geochimica et Cosmochimica Acta, 64: 169-183.

Turin H.J. \& Plummer M.A., 2000 - Lechuguilla Cave pool chemistry, 1986-1999. Journal of Cave and Karst Studies, 62: $135-143$.

USEPA, 1983 - Methods for chemical analysis of water and wastes. EPA-600/4-79-20. U.S. Environmental Protection Agency, Cincinnati, Ohio (USA), 552 p.

Viollier E., Jezequel D., Michard G., Pepe M., Sarazin G. \& Alberic P., 1995 - Geochemical study of a crater lake (Pavin Lake, France): trace element behavior in the monimolimnion. Chemical Geology, 125: 61-72.

Wilson W.L. \& Morris T.L., 1994 - Cenote Verde: A meromictic karst pond, Quintana Roo, Mexico. In: Sasowsky I. \& Palmer M.V. (Eds.) - Breakthroughs in karst geomicrobiology and redox geochemistry. Karst Waters Institute, Inc., Charles Town, West Virginia (USA): 77-79. 